\section{Social representations of adolescents on sexual relations and the use of condoms}

\author{
Representações sociais de adolescentes \\ acerca da relação sexual e do uso do preservativo
}

Representaciones sociales de adolescentes

sobre la relación sexual y el uso del preservativo

\author{
Elys de Oliveira Bezerra ${ }^{a}$ \\ Maria Lúcia Duarte Pereirab \\ Ana Clara Patriota Chaves ${ }^{c}$ \\ Priscila de Vasconcelos Monteiro ${ }^{d}$
}

\begin{abstract}
The objective of this investigation was to identify how adolescents structure the social representations of sexual intercourse and use of condoms. Exploratory and descriptive research was conducted with a convenience sample consisting of 234 students of a public secondary school in Fortaleza-CE, Brazil, between July 2009 and April 2010. Data were collected using a questionnaire with variables on socioeconomic status and sexual behaviour, and Free Association test with three terms: 'sex,', unprotected sex' and 'sex with a condom'. Sexual intercourse was represented by love and affection among the women, while men associated sex to pleasure, desire and attraction toward the female body. The condom was considered important by both groups, but men represented condoms as being something bad that restricts pleasure. Health professionals are granted the opportunity to identify vulnerabilities of this population to DST/HIV/AIDS and work with these vulnerabilities in the most appropriate way.
\end{abstract}

Keywords: Sexually transmitted diseases. HIV. Condoms. Adolescent.

\section{RESUMO}

0 objetivo da investigação foi identificar como se estruturam as representações sociais sobre relação sexual e uso do preservativo para adolescentes. Pesquisa exploratória e descritiva, realizada com amostra não probabilística de conveniência constituída por 234 alunos do ensino médio de uma escola pública de Fortaleza (CE), entre julho de 2009 e abril de 2010. Utilizou-se questionário com variáveis sobre nível socioeconômico e comportamento sexual e um Teste de Associação Livre de Palavras com três estímulos indutores: sexo, sexo sem camisinha e sexo com camisinha. A relação sexual foi representada por amor e sentimentos afetivos entre as mulheres, enquanto os homens a representavam por prazer, desejo e atração pelo corpo feminino. A camisinha foi considerada importante em ambos os grupos, porém os homens a representavam como algo ruim e que dificulta ou não oferece prazer. 0 profissional tem a oportunidade de identificar vulnerabilidades às DST/HIV/aids, permitindo-Ihe trabalhá-las da forma mais adequada.

Palavras-chave: Doenças sexualmente transmissíveis. HIV. Preservativos. Adolescente.

\section{RESUMEN}

El objetivo de la investigación fue identificar la forma de estructurar las representaciones sociales de las relaciones sexuales y el uso de condones para los adolescentes. Investigación exploratoria y descriptiva entre muestra de conveniencia no probabilística compuesta por 234 estudiantes de secundaria de una escuela pública de Fortaleza-CE, entre julio de 2009 y abril de 2010. Se utilizó cuestionario que incluía artículos sobre la situación socioeconómica y el comportamiento sexual y un Test de Asociación Libre de Palabras con tres estímulos: sexo, sexo sin protección y sexo con condones. La relación sexual estuvo representada por el amor y los sentimientos afectivos entre las mujeres, mientras que los hombres representados en el placer, el deseo y la atracción por el cuerpo femenino. Al condón se lo consideró importante en ambos grupos, pero los hombres lo hizcieron como algo malo y que hace que sea difícil o no ofrece placer. El profesional tiene la oportunidad de identificar las vulnerabilidades a las EST/VIH/SIDA, que le permite trabajar en la manera más apropiada.

Palabras clave: Enfermedades de transmisión sexual. VIH. Condones. Adolescentes.
D0l: http://dx.doi.org/10.1590/19831447.2015.01.45639 


\section{DINTRODUCTION}

HIV infection is a worldwide multifactorial phenomenon that affects various sectors of society without prejudice of colour, gender, social class or age group. In Brazil, the HIV/AIDS epidemic has grown in the past 10 years and the detection rate has risen by around 2\%. A total of 39,185 cases were reported in 2012 and this number has a tendency to grow among teenagers and youths ${ }^{(1)}$.

Although adolescents and youths have more information on how to prevent AIDS and other sexually transmitted diseases, and use condoms with a higher frequency than other age groups, HIV infection rates are higher among this population, which reveals a greater vulnerability to this disease ${ }^{(2)}$

Adolescence is a period of life characterized by intensive biological, social and economic transformations. These transformations generate new experiences that, together with their inexperience, can increase vulnerabilities and risks(3).

The concept of vulnerability seeks to understand how individuals and groups are exposed to health issues based on complex realties and the analysis of three dimensions: individual, which includes biological, behavioural and affective aspects; social, which addresses the life context of the subjects and their social relations; and programmatic, which encompasses policies, programmes, services and actions that influence the situation ${ }^{(4)}$.

There are several factors of sexual vulnerability of adolescents to this epidemic, such as the early discovery of sexuality, the multiplicity of partners, greater sexual freedom, doubts on preventing its transmission, the need for affirmation, and refusal and resistance to the use of condoms ${ }^{(5)}$.

Given the prevalence of HIV transmission via sexual intercourse among adolescents, this paper approaches issues related to sexuality, sex and the use of condoms.

Sexuality is a form of expression, communication and affection that is revealed in relationships and is influenced by values, rules and the time and space in which we live. Sex, on the other hand, is a form of expressing our sexuality ${ }^{(6)}$.

It is important to understand and accompany the development of sexuality and the biopsychosocial context that permeates this development to detect the specific needs of adolescents. This knowledge can guide national public health care policies and provide a basis for SDT/HIV/ AIDS prevention and control actions.

Thus, to better apprehend the development of sexuality and the vulnerability of youths exposed to STD/HIV/ AIDS, the aim of this study is to identify how adolescents structure the social representations of sexual relations and the use of condoms.
The theoretical framework selected for this study was the Social Representations Theory. Social representations are the knowledge that makes up the interpretation of reality and governs the relationships of individuals with their physical and social environment, and how these relationships determine their behaviour and practices ${ }^{(7)}$.

The basis of this behaviour can be the social representations shared by a group in relation to a given social object. These representations direct the way subjects relate to each other, with the group and with the world, and influence their behaviour and attitudes ${ }^{(7)}$.

Studies on social representations provide an understanding of the attitudes and behaviours of certain groups within a given reality, which helps nurses to plan interventions more effectively ${ }^{(8)}$ in the realms of health care and epidemic prevention, and when providing care for youths who have already acquired immunodeficiency.

\section{METHODOLOGY}

This is an exploratory, descriptive study conducted at a state-owned public secondary school of the Secretaria Executiva Regional IV (SER IV) in the municipality of Fortaleza, Ceará, Brazil, from July 2009 to April 2010. The school was selected because it is located in the same territory as the university that proposed this research.

The school population was 1105 students between the ages of 10 and 19, but the study sample was 234 adolescents, according to the finite population correction. This criteria considered a sampling error of $5 \%$, reliability of 95\% and that 30\% were attending secondary school. The study group was selected using non-probability sampling according to the following inclusion criteria: enrolled at the secondary school; attending the secondary school; able to read and write. Exclusion criteria were foreign adolescents or adolescents with a deficiency than prevented them from participating in the study.

Two self-applied questionnaires were distributed in the classroom. A semi-structured questionnaire was used to collect sociodemographic data and data related to the subjects'sex life. The adopted method to investigate social representations was a Free-Association test.

This test consists of "providing stimulus words related to the topic of the study so participants can associate words or expressions that spontaneously come to mind as soon as they hear these words" ${ }^{\prime \prime(8)}$. Three terms were used for this research: 'sex,', 'unprotected sex' and 'sex with a condom'.

Data were analyzed using statistical descriptions (relative frequency, mean and median) with the Statistical Package for Social Sciences - SPSS 16.1. 
Data of the Free Association test were processed using the Ensemble de Programmes Permettant L'analyse des Evocations - EVOC ${ }^{(9)}$, that calculates and notifies the simple frequency of occurrence of each word, weighted average according to the order of evocation and average of the weighted average order of the set of evoked terms ${ }^{(10)}$. The adopted cut-off point was above 10 and a rank under the absolute value of 3 .

One of the results of EVOC software is a matrix of four quadrants. The first quadrant in the upper left corner corresponds to elements that are likely to form the core of a given representation. These elements are the terms that were more readily and more frequently evoked. The core is the main element of a representation and hardly varies with time or circumstances ${ }^{(9)}$. It also renders meaning and coherence to a representation. The periphery acts as a protective belt around the core and prevents its refutation ${ }^{(11)}$.

The second upper right quadrant contains the most frequently evoked elements, although these elements are the least important to the subject. This quadrant corresponds to the first periphery, which has the function of protecting the core. The third quadrant, in the bottom right, corresponds to elements of the second periphery that were evoked less frequently and in the last positions. The fourth quadrant, bottom left, corresponds to contrast elements mentioned in the first positions by some subjects. As these elements were not cited by many subjects, they remain in the bottom lower quadrant to show their contrast with the core, thus representing subjects with important but diverging opinions ${ }^{(12)}$.

Data were analyzed from the perspective of social representations, and arranged according to the core, elements of the first periphery, elements of the second periphery and element of contrast. The social representations of the female group were subsequently compared to the social representations of the male group.

Research was approved by the Research Ethics Committee of the Universidade Estadual do Ceará, under protocol number 08517555, in accordance with the determinations of Resolution 196/96 of the National Health Council on research involving human beings ${ }^{(13)}$. All participants and their guardians signed an informed consent statement.

\section{口ESULTS}

\section{Profile of the adolescents}

The adolescents of the sample were equally distributed in terms of gender (117 were male and 117 were female), with an average age of $16.5(( \pm 2.5)$, and they were all at- tending secondary school. Most students were in their first year (98); 41.9\%); were Catholic (142; 60.7\%) and lived with their parents/family $(165 ; 71.1 \%)$. Average family income was three minimum wages (considering that the minimum wage at that time was BRL 465.00).

Among the sample, $46.5 \%$ (108) reported they had already initiated sexual intercourse. Of these individuals, $64.8 \%$ (70) were male. Average age of the first sexual relationship was 14.7 years ( \pm 3 .2). Table 1 shows the results referent to use of condoms by adolescents during their first and last sexual encounter.

Most of these adolescents had had sexual intercourse in the last 12 months $(88 ; 81.5 \%)$ and reported having used a condom in the first encounter $(64 ; 59.2 \%)$ and in the last sexual encounter $(74 ; 68.5 \%)$. A considerable portion of the sample, however, did not use a condom in the first encounter $(44 ; 40.8 \%)$ or the last encounter $(34 ; 31.5 \%)$.

\section{The structure of social representations of sexual intercourse and the use of condoms}

Chart 1 shows the structure of social representations of sex for the male and female groups.

The core or the most frequently and readily evoked words of the female group were 'love' (97-rank 1.93) and 'pleasure' (72- rank 2.41), while the core of the male group was represented by the words 'women' (26 - rank 2.34) and 'pleasure' (81 - rank 2.07).

The first peripheral elements among women were 'condom', 'affection', and 'pregnancy', and the first peripheral elements among the men were 'love', 'condom,', 'lust' and 'desire.' The second peripheral elements among women were 'child', 'life' and 'precaution', while men mentioned 'disease', 'pregnancy' and 'good'. The contrasting elements of the male and female groups were 'man,' 'oral,' 'prevention', and 'safety'.

There were no significant differences between the two groups in relation to the social representations of the stimulus term 'unprotected sex.' For the female group, the core consisted of 'disease,' 'STD', 'child' and 'pregnancy'. The core of the male group consisted of the words 'AIDS', 'disease', 'STD','child,' 'pregnancy' and 'danger', as shown in Chart 2.

There were some important differences between the peripheral elements of the groups. The first peripheral elements that emerged were 'HIV', insecurity' and 'irresponsibility', however, the men also mentioned the element'pleasure'. In the female group, the second peripheral elements that emerged were 'inattention', 'misinformation' and 'ignorance.' The men, however, mentioned the words 'regret', 'good' and 'pleasurable.'. Only the female group presented 
Table 1. Sample distribution according to sex and use of condoms in the first and last sexual encounter, Fortaleza - CE, Brazil/2010

\begin{tabular}{lcccccc} 
& \multicolumn{2}{c}{ Male } & \multicolumn{2}{c}{ Female } & \multicolumn{2}{c}{ Total } \\
& $\mathbf{N}$ & $\%$ & $\mathbf{N}$ & $\%$ & $\mathbf{N}$ & $\%$ \\
$\begin{array}{l}\text { Condom use during first sexual encounter } \\
\quad \text { Yes }\end{array}$ & & & & & & \\
$\quad$ No & 37 & 34.3 & 27 & 25.0 & 64 & 59.3 \\
$\quad$ Total & 33 & 30.5 & 11 & 10.2 & 44 & 40.7 \\
Condom use during last sexual encounter & 70 & 64.8 & 38 & 35.2 & 108 & 100.0 \\
$\quad$ & & & & & & \\
$\quad$ Yes & 50 & 47.6 & 24 & 22.9 & 74 & 70.5 \\
$\quad$ No & 19 & 18.1 & 12 & 11.4 & 31 & 29.5 \\
Total & 69 & 65.7 & 36 & 34.3 & 105 & 100.0 \\
\hline
\end{tabular}

Source: Research data, 2010

\begin{tabular}{|c|c|c|c|c|c|c|}
\hline \multicolumn{2}{|c|}{ Core } & $\mathbf{F}$ & Rank & Peripheral elements 1 & $\mathbf{F}$ & Rank \\
\hline \multirow{3}{*}{ Female } & Love & 97 & 1.93 & Condom & 43 & 2.60 \\
\hline & \multirow{2}{*}{ Pleasure } & \multirow{2}{*}{72} & \multirow{2}{*}{2.41} & Affection & 32 & 2.81 \\
\hline & & & & Pregnancy & 20 & 3.00 \\
\hline \multirow{4}{*}{ Male } & \multirow{2}{*}{ Pleasure } & \multirow{2}{*}{81} & \multirow{2}{*}{2.07} & Love & 71 & 2.52 \\
\hline & & & & Condom & 33 & 3.03 \\
\hline & \multirow{2}{*}{ Women } & \multirow{2}{*}{26} & \multirow{2}{*}{2.34} & Lust & 22 & 2.68 \\
\hline & & & & Desire & 19 & 3.63 \\
\hline \multicolumn{2}{|c|}{ Elements of contrast } & $\mathbf{F}$ & Rank & Peripheral elements 2 & $\mathbf{F}$ & Rank \\
\hline \multirow{3}{*}{ Female } & \multirow{3}{*}{ Man } & \multirow{3}{*}{6} & \multirow{3}{*}{2.00} & Child & 7 & 2.71 \\
\hline & & & & Life & 5 & 2.80 \\
\hline & & & & Precautions & 9 & 3.11 \\
\hline \multirow{3}{*}{ Male } & Oral & 5 & 2.00 & Diseases & 9 & 2.88 \\
\hline & Prevention & 5 & 2.00 & Pregnancy & 5 & 3.00 \\
\hline & Safety & 5 & 2.20 & Good & 7 & 3.14 \\
\hline
\end{tabular}

Chart 1. Distribution of social representations according to gender for the word sex, Fortaleza - CE, Brazil/2010

Source: Research data, 2010.

an element of contrast that was represented by the word 'foolishness'.

For the social representations of the stimulus term 'sex with a condom', both groups created a core with the words 'protection', 'safety,' 'responsibility' and 'tranquillity'. The elements of the first periphery for both sexes were also similar and consisted of 'love', trust' and 'awareness', although the women mentioned 'care' and the men mentioned 'unpleasurable' in relation to the term. The elements of the second periphery in the female group were 'maturity', intelligence' and 'health'. In the male group, the words were 'correct' and 'childless.' The elements of contrast provided by the men were'relief' and 'bad. These results are shown in Chart 3.

\section{DISCUSSION}

Results show that adolescents initiate their sex life early and are therefore exposed to STD/HIV/AIDS at a young age. 


\begin{tabular}{|c|c|c|c|c|c|c|}
\hline \multicolumn{2}{|c|}{ Core } & $\mathbf{F}$ & Rank & Peripheral elements 1 & $\mathbf{F}$ & Rank \\
\hline \multirow{4}{*}{ Female } & Disease & 81 & 2.00 & HIV & 12 & 2.91 \\
\hline & STD & 19 & 2.05 & Insecurity & 19 & 3.52 \\
\hline & Child & 19 & 2.26 & \multirow{2}{*}{ Irresponsibility } & \multirow{2}{*}{49} & \multirow{2}{*}{2.93} \\
\hline & Pregnancy & 81 & 2.18 & & & \\
\hline \multirow{6}{*}{ Male } & AIDS & 26 & 2.07 & HIV & 12 & 2.58 \\
\hline & Disease & 70 & 1.95 & Insecurity & 27 & 3.00 \\
\hline & STD & 15 & 1.86 & \multirow{2}{*}{ Irresponsibility } & \multirow{2}{*}{31} & \multirow{2}{*}{3.25} \\
\hline & Child & 36 & 2.36 & & & \\
\hline & Pregnancy & 59 & 2.30 & \multirow{2}{*}{ Pleasure } & \multirow{2}{*}{20} & \multirow{2}{*}{3.50} \\
\hline & Danger & 12 & 2.00 & & & \\
\hline \multicolumn{2}{|c|}{ Elements of contrast } & $\mathbf{F}$ & Rank & Peripheral elements 2 & $\mathbf{F}$ & Rank \\
\hline \multirow{3}{*}{ Female } & \multirow{3}{*}{ Foolishness } & \multirow{3}{*}{9} & \multirow{3}{*}{2.00} & Inattention & 6 & 3.83 \\
\hline & & & & Misinformation & 6 & 3.66 \\
\hline & & & & Ignorance & 7 & 3.28 \\
\hline \multirow{3}{*}{ Male } & \multirow{3}{*}{-} & \multirow{3}{*}{-} & \multirow{3}{*}{-} & Regret & 5 & 4.20 \\
\hline & & & & Good & 8 & 3.12 \\
\hline & & & & Pleasurable & 5 & 3.40 \\
\hline
\end{tabular}

Chart 2. Distribution of social representations according to gender for the term unprotected sex, Fortaleza - CE, Brazil/2010 Source: Research data, 2010.

Among the adolescents who reported having had sexual intercourse, most of them used a condom. There was a higher frequency of condom use in the last sexual encounter in comparison to the first, which corroborates other studies ${ }^{(11,14)}$.

Sexual initiation generally occurs during adolescence, although the social lives, economy and culture of each individual influences this initiation in several ways. Other influencing factors are the social representations of sexual intercourse and use of condoms that are shared and expressed within a group.

For the female group, sexual intercourse is associated to 'love' and 'pleasure', both of which were added to the core of the matrix. This reveals the profound and fundamental meaning they attribute to sex. They emphatically referred to pleasure as something that integrates and represents sex, which differs from previous generations that did not freely express their own sexuality. Women believe that a relationship based on love, care and affection is an essential and decisive requirement for sexual intercourse to occur(15).

Other elements, such as 'condoms', 'life' and 'precautions', show that the women perceived the need to use condoms during a sexual act as a way of protecting their health, and felt responsible for their sex lives. This percep- tion of the importance of condoms was higher among the women than among the men ${ }^{(16)}$. Although gender issues are still rooted in practices and behaviour that involve sexuality, the adolescents in this study showed greater autonomy in relation to condom use.

Among the men, the core of representations of sexual intercourse consisted of the words 'women' and 'pleasure', which reveals the association of sex to the number of women and to physical pleasure. This representation is encouraged by society as a form of masculine virility ${ }^{(15)}$. Elements in the first periphery were 'love,' 'condom,' 'lust' and 'desire.' The men valued meaningful sex by mentioning 'love' in relation to sex, although they considered sex without having feelings for their partner as being normal, as if it were an attribute of "being a man" due to the nature of manhood or the encouragement of their parents or group of friends $s^{(15,17-18)}$.

They also considered that the female body is profoundly connected to desire and pleasure ${ }^{(17)}$, which was revealed by their use of the words 'lust' and 'desire'. This confirms the popular belief that, for men, sex is essentially related to physical attraction and instant pleasure.

In relation to sexual intercourse without a condom, the social representations were similar between the groups, 


\begin{tabular}{|c|c|c|c|c|c|c|}
\hline \multicolumn{2}{|c|}{ Core } & $\mathbf{F}$ & Rank & Peripheral elements 1 & $\mathbf{F}$ & Rank \\
\hline \multirow{4}{*}{ Female } & Protection & 17 & 2.41 & Love & 12 & 2.91 \\
\hline & Responsibility & 52 & 2.44 & Trust & 19 & 3.52 \\
\hline & \multirow{2}{*}{ Safety } & \multirow{2}{*}{70} & \multirow{2}{*}{1.77} & Awareness & 49 & 2.93 \\
\hline & & & & Precautions & 14 & 2.71 \\
\hline \multirow{4}{*}{ Male } & Protection & 27 & 2.48 & Love & 17 & 2.94 \\
\hline & Safety & 79 & 1.60 & Trust & 11 & 3.36 \\
\hline & \multirow{2}{*}{ Tranquillity } & \multirow{2}{*}{11} & \multirow{2}{*}{2.09} & Awareness & 12 & 3.25 \\
\hline & & & & Unpleasurable & 11 & 3.18 \\
\hline \multicolumn{2}{|c|}{ Elements of contrast } & $\mathbf{F}$ & Rank & Peripheral elements 2 & $\mathbf{F}$ & Rank \\
\hline \multirow{3}{*}{ Female } & \multirow{3}{*}{ - } & \multirow{3}{*}{ - } & \multirow{3}{*}{ - } & Maturity & 7 & 2.57 \\
\hline & & & & Intelligence & 8 & 2.75 \\
\hline & & & & Health & 9 & 2.77 \\
\hline \multirow{2}{*}{ Male } & Relief & 8 & 2.25 & Correct & 9 & 2.77 \\
\hline & Bad & 6 & 2.00 & Childless & 8 & 2.87 \\
\hline
\end{tabular}

Chart 3. Distribution of social representations according to gender for the word sex with a condom, Fortaleza - CE, Brazil/2010.

Source: Research data, 2010.

and the core consisted of the words 'disease', 'STD', 'child' and 'pregnancy'. The adolescents mentioned 'STD' and 'pregnancy' as a consequence of unprotected sex, which shows that they perceive the risk of AIDS ${ }^{(19)}$.

The word 'pregnancy' was of greater significance to the women than to the men. In relation to sex, the greatest fear among the women was still pregnancy due to the cultural burden ${ }^{(15)}$, where men hold women accountable for preventing pregnancy ${ }^{(17)}$.

Unprotected sex was also associated to 'inattention', 'misinformation' and 'ignorance' in the women's group, which supports the belief that lack of information essentially leads to unprotected sex. However, preventive practices adopted by these youths are determined by representational content that is not usually related to the cognitive knowledge they mentioned. Although the level of education and schooling are factors that are associated to a more frequent use of condoms, these factors are not sufficient to ensure consistent prevention ${ }^{(16,20)}$.

There are several factors of individual and social vulnerability that compromise the effective use of condoms. In the male group, there was a social representation that sex without a condom is 'good' and 'pleasurable', that is, it offers pleasure and satisfaction despite the association with disease and pregnancy. In congruence with this finding, there was also the representation that sex with a condom is unpleasurable, bad or uncomfortable, although it was acknowledged as being safe.

A study ${ }^{(17)}$ with adolescents identified social representations of safe sex as being sexual intercourse with a condom, although many of the subjects reported that they did not always use condoms. Social representations in the male universe on the prevention of STD and the effective use of condoms constructed and shared by the group for generations are based on denial when considering the use of condoms.

Although the men in this study acknowledged that protected sex is positive and correct, they also believe that the condom inhibits their pleasure and satisfaction. Moreover, their words show that they think protected sex may affect their performance, which is related to impotence, or may even be uncomfortable ${ }^{(18)}$. When these social representation are shared and promoted, they can inhibit use of condoms and increase their vulnerability to STD/HIV/AIDS.

The cores of social representations of sex with a condom were similar for both sexes. The adolescents associated 'safety', 'protection', 'responsibility' and 'tranquillity' to sex with a condom, which shows they understand that condoms are the main method for preventing STD/HIV/ $\operatorname{AIDS}^{(19)}$.

This preventive attitude among teenagers seems to be linked to love and trust toward their partner ${ }^{(19)}$. Such 
an attitude was also referred to as 'health' in the female group, which shows the positive concept of health related to disease prevention and the subjects' responsibility in this process.

\section{GINAL CONSIDERATIONS}

In spite of some limitations with regard to the samples and the scenario, this study concludes that the social representations of sex and the use of condoms are perceived differently by men and women. The female group structured its representation of sex around love and pleasure and always mentioned elements related to affection. The men, on the other hand, elaborated representations based on the female body and pleasure, and therefore associated sexual intercourse to attraction and physical elements.

These social representations show associations with relations of gender and power that exist in society and are intrinsic in our culture. These representations show that adolescent girls have a greater tendency to value love, sentiment and commitment, while adolescent boys seem to value ephemeral relationships. Consequently, the ideal of love, a stable relationship and trust does not allow women to negotiate the use of condoms with their partners. Men, on the other hand, become involved in several relationships to prove their virility, which leads to greater exposure. Both situations create vulnerabilities to STD.

For both groups, sex without a condom was associated to diseases and pregnancy. Pregnancy was more significant among the women, as culturally they are held responsible for reproduction and this evidently has a great impact on their lives. Among the men, not using a condom was considered as being good and pleasurable, while using a condom during sex was believed to be unpleasurable and bad. These social representations of condom use create a vulnerability to STD/AIDS.

Issues related to gender, power, culture, and common sense among adolescents involve constructed social representations that are fundamental when they decide to initiate a sexual act and to use a condom, and when they define relationships, sexual intercourse and preventive measures. Beliefs, taboos and myths that the condom reduces pleasure and causes impotence or discomfort also have a negative influence on the use of this method.

Social representations are therefore powerful factors for determining vulnerability to STD/HIV/AIDS, since common sense can change people's attitudes toward prevention. Health care professionals, especially nurses, should consider these representations during consultations, counselling and when providing health-related orientation.
By knowing how adolescents represent sex, health care professionals can talk about this subject with them in a more direct and objective way. From this standpoint, professionals can more easily identify vulnerabilities and work with them according to the universe created by youths and adolescents. This will enable these professionals to demystify some of the social representations and provide more effective health education. Health education that is based on the social representations of adolescents in relation to STD/AIDS, sex and the use of condoms will help nurses closely participate in the experiences and culture of this group, and subsequently support the promotion of health.

\section{口EFERENCES}

1. Ministério da Saúde (BR). Secretaria de Vigilância em Saúde, Departamento de DST, Aids e Hepatites Virais. Bol Epidemiol HIV aids. 2013 Dec; 2 (1): 1-64.

2. Ministério da Saúde (BR). Secretaria de Vigilância em Saúde, Departamento de DST, Aids e Hepatites Virais. Pesquisa de conhecimentos, atitudes e práticas na população brasileira de 15 a 64 anos, 2008. Brasilia: Ministério da Saúde; 2011. $130 \mathrm{p}$.

3. Saints SM, Oliveira MLF. Conhecimento sobre aids e drogas entre alunos de graduação de uma instituição de ensino superior do estado do Paraná. Rev Latino-am Enfermagem. 2009; 17 (4): 522-8.

4. Ayres JRCM. Organização das açōes de atenção à saúde: modelos e práticas. Saude Soc [Internet]. 2009 jun [cited 2014 nov 8];18(Suppl 2):11-23. Available at: http://www.scielo.br/scielo.php? script=sci_arttext\&pid=S0104-12902009000600003\&lng=en. http://dx.doi.org/10.1590/5010412902009000600003.

5. Barreto ACM, Santos RS. A vulnerabilidade da adolescente às doenças sexualmente transmissíveis: contribuições para a prática da Enfermagem. Esc Anna Nery Rev Enferm. 2009;13(4):809-16.

6. Ministério da Saúde (BR). Secretaria de Vigilância em Saúde, Departamento de DST, Aids e Hepatites Virais. Adolescentes e jovens para a educação entre pares: saúde e prevenção nas escolas. Brasilia: Ministério da Saúde; 2010.68 p.

7. Moscovici S. Representaçôes sociais: investigaçoes em psicologia social. 8. ed. Petrópolis, RJ:Vozes; 2011.

8. Silva SD, Camargo BV, Padilha MI. A teoria das representaçoes sociais nas pesquisas da enfermagem brasileira. Rev Bras Enferm. 2011;64(5):947-51.

9. Vergès, P. Ensemble de programmes permettant l'analyse des evocations: manuel version 2. Aix-en-Provence: LAMES; 1999.

10. Reis AOA, Sarubi JúniorV, Bertolino Neto MM, Rolim Neto ML. Tecnologias computacionais para o auxilio em pesquisa qualitativa: software EVOC. São Paulo: Schoba; 2013.

11. Doreto DT, Vieira EM. 0 conhecimento sobre doenças sexualmente transmissíveis entre adolescentes de baixa renda em Ribeirão Preto, São Paulo, Brasil. Cad Saúde Pública. 2007;23(10):2511-6.

12. Wagner W, Hayes N, Palacios FF, editores. El discurso de lo cotidiano y el sentido común: la teoría de las representaciones sociales. Barcelona: Anthropos; 2011.

13. Ministério da Saúde (BR). Conselho Nacional de Saúde. Resolução no 196, de 10 de outubro de 1996. Diretrizes e normas regulamentadoras de pesquisas envolvendo seres humanos. Diário Oficial [da] República Federativa do Brasil. 1996 out 16;134(201 Seção 1):21082-5. 
14. Paiva V, Calazans G, Venturi G, Dias R. Idade e uso de preservativo na iniciação sexual de adolescentes brasileiros. Rev Saúde Pública. 2008:42(Suppl.1):45-53.

15. Amaral MA, Fonseca RMGS. Entre o desejo e o medo: representações sociais das adolescentes acerca da iniciação sexual. Rev Esc Enferm USP. 2006:40(4):469-76.

16. Natividade JC, Camargo BV. Representações sociais, conhecimento científico e fontes de informação sobre aids. Paidéía. 2011;21(49):165-74.

17. Oliveira DC, et al. "Pegar","ficar" e "namorar": representações sociais de relacionamentos entre os jovens. Rev Bras Enferm. 2007;60(5):497-502.
18. Alves MFP. Sexualidade e prevenção de DST/aids: representações sociais de homens rurais de um município da zona da mata pernambucana, Brasil. Cad Saúde Pública. 2003;19(Supl. 2):S429-39.

19. Bousfield ABS, Camargo BV. Divulgação do conhecimento científico sobre aids e representações sociais. Acta Colomb Psicol. 2011;14(1):31-45.

20. Teixeira AMFB, Knauth DR, Fachel JMG, Leal AF. Adolescentes e uso de preservativos: as escolhas dos jovens de três capitais brasileiras na iniciação e na última relação sexual. Cad Saúde Pública. 2006;22(7):1385-96.

\section{Author's address:}

Elys Oliveira Bezerra.

Rua Inglaterra, 150, Itaperi

60714-150, Fortaleza, CE

E-mail: elysoliveira@gmail.com
Received: 14.03.2014

Approved: 05.12.2014 